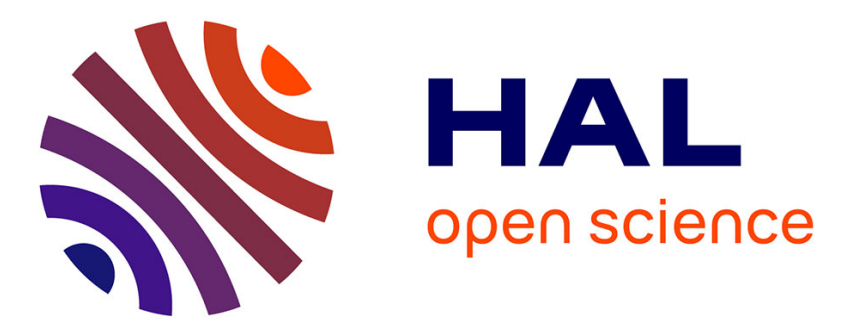

\title{
Livestock farming and nitrogen within the economic and social context
}

Alexandra Langlais, Christian C. Nicourt, Magalie Bourblanc, Carl Gaigné

\section{To cite this version:}

Alexandra Langlais, Christian C. Nicourt, Magalie Bourblanc, Carl Gaigné. Livestock farming and nitrogen within the economic and social context. Advances in Animal Biosciences, 2014, 5 (1), pp.2027. $10.1017 / \mathrm{S} 2040470014000260$. halshs-01137456

\section{HAL Id: halshs-01137456 \\ https://shs.hal.science/halshs-01137456}

Submitted on 27 May 2020

HAL is a multi-disciplinary open access archive for the deposit and dissemination of scientific research documents, whether they are published or not. The documents may come from teaching and research institutions in France or abroad, or from public or private research centers.
L'archive ouverte pluridisciplinaire HAL, est destinée au dépôt et à la diffusion de documents scientifiques de niveau recherche, publiés ou non, émanant des établissements d'enseignement et de recherche français ou étrangers, des laboratoires publics ou privés. 


\title{
Livestock farming and nitrogen within the economic and social context
}

\author{
A. Langlais ${ }^{1 \dagger}$, C. Nicourt ${ }^{2}$, M. Bourblanc ${ }^{3}$ and C. Gaigné ${ }^{4}$ \\ ${ }^{1}$ CNRS laboratory 6262, IODE, University Rennes F-35042 Rennes cdx, France, ${ }^{2} I N R A$, RITME, F-94200 Ivry-sur-Seine, France; ${ }^{3}$ CIRAD, Research unit G-EAU \\ (Montpellier, France)/ CEEPA, University of Pretoria, South Africa; ${ }^{4}$ INRA Rennes, Research Unit 1302 SMART, F-35042 Rennes Cedex, France
}

\begin{abstract}
Scientific literature in social sciences that deals with nitrate embraces two centuries, whereas very little socio-economic work has addressed other forms of reactive nitrogen. Nitrogen has always had an ambivalent role as both a raw material indispensable for the development of agricultural and a source of negative impacts. This ambivalence has accompanied the social history of livestock production and can explain the conflicting nature of the subject and the moderate environmental efficiency of environmental policies. The legal system is particularly complex. The main cause of territorial pollutions is linked to the industrialisation and spatial concentration of livestock production in France, as in numerous countries in Europe and North America. This conglomeration movement is translated by a concentration of animal manure, which drives to nitrogen balance surplus and associated serious environmental consequences.
\end{abstract}

Keywords: nitrate pollution, environmental regulation, zoning, agrifood industry

\section{Nitrogen: fertiliser or pollutant? The origin of a society issue}

Origin of the legal context in the 19th century: olfactory nuisances

In France, the issue of odours from livestock housing, storing or spreading manure was the starting point of the social history of nitrogen even if these odours are not the sole result of nitrogen compounds, but more generally are from animal excretions. These olfactory nuisances are the basis of laws on pollutions and industrial risks. In the 19th century, foul odours were associated with the theory of 'miasmas', the principle of unknown causes of the aetiology of epidemics. The Imperial Decree of 15 October 1810 'concerning factories and workshops that spread an unsanitary or unpleasant odour' was the foundation of the legal framework governing the relations between economic activities and their environment (Massard-Guilbaud, 2010). This Decree included pig farms in the class of establishments 'for whose creation it is necessary to obtain authorisation from the Interior Ministry'. It stipulated that cohabitation of differing interests involved distance requirements for according to three classes of negative impacts (swine farms were in the first class, cattle farms were in the second and the third did not involve negative impacts for residences but had to 'remain subjected to the surveillance of the police').

\footnotetext{
E-mail: alexandra.langlais@univ-rennes1.fr
}

Nitrogen, the driving factor of agricultural productivity in the 20th century

The 20th century was marked by the explosion of industrial chemistry and chemical fertilisation became progressively indispensable and a sign of modernity. After World War II, the Marshall Plan supported the manufacture of industrial fertilisers to increase agricultural production (Coquery, 1952). For the new generation of breeders at the time, the specialisation of agricultural production systems was the death knell of an agriculture where the peasant who produced 'a bit of everything' was required to become a 'professional'. Industrial livestock farming systems became the emblematic expression of a new form of livestock production, less intimately related to the land than before (Rémy, 1987). Although cattle farms are still based on farm resources to feed animals, for pigs and poultry livestock housing is the rule and specialised breeding activities replaced collective work in fields and local and family ties. This development model led to considerable productivity increases and contributed to what was called the 'Breton economic miracle'. The expansion of agricultural production became the leading economic engine and regional employer and powerful groups of producers emerged (Gervais et al., 1965; Barles and Lestel, 2007).

Work of associations and dynamics of the social debate Legislation and regulations initially addressed health improvement of herds and it was only later that intensive forms of livestock production became part of the environmental 
debate. Several sociology works placed the 'environmental turning point' in the 1970s. Reported and supported by the media, criticism of agricultural practices and their impact on water quality progressively came into the social debate under the combined pressure of rural inhabitants, in particular those living close to livestock farms, and environment protection associations. In Brittany, where this social debate was and still is intense, associations for defence of the environment concentrated their efforts around the quality of water (Pierre et al., 2008). Although agricultural professionals stressed the limited availability of land with respect to the number of farmers, associations insisted on the geographic concentration of livestock farming systems. Among the first in this area, the association 'Eau et Rivières de Bretagne' (Water and Rivers of Brittany) first denounced the complacency and lack of respect for others by those responsible for the development of livestock farming systems, and subsequently changed their course by adopting a legal strategy. In 1992, a lawsuit was filed with European instances for non-respect of obligations of the Water Quality Directive (suitability for drinking water). This legal action resulted in the French government being found guilty first in 2001 and again in 2007, leading to considerable pressure applied on France by the European Union. At the same time, the impact of nitrate on public health was placed in the forefront of media interest and again became the subject of a scientific controversy (Powlson et al., 2008), whereas heavy negative impacts of gaseous forms of nitrogen (largely owing to agriculture for part of them) were pointed in the European nitrogen assessment.

The work of Breton associations was supported by national actions of associations such as WWF, France Nature Environment, etc. (Autissier, 2010), showing the capacity of these associations to call public decisions into question and to propose alternatives (Ollitrault, 2001). Scientific work analysed the role of associations in changes being made and progress in their position after their institutionalisation in local politics (Le Bourhis and Silvia, 2007).

\section{Contested management of nitrogen impacts on the image of} breeders

Considerable work in sociology and geography analysed relations between 'rural-urban' populations and agriculture as more and more homes were built in rural areas starting in the 1970s: 'rurbanisation' (Perrier-Cornet, 2003; Banos and Candau, 2006). On the one hand, new residents discovered 'industrialised' agriculture. On the other, livestock farmers (and more broadly farmers in general) were faced with the expectations of these new users and a new type of land use requiring more or less to reorganise fields plots and their use. The requirement of a distance from homes considerably changed manure spreading practices and the issue of odours was again front-page news. Neighbouring populations started to associate olfactory nuisances with water pollutions.

In the early 2000s, conflicts on the use of animals waste increased significantly (Guérin, 2005). This author pointed out that public inquiries preceding the installation or extension of livestock farming systems did not always dampen debates when they existed. In actual fact, the Prefectoral Authorisation Decree, that was supposed to conclude the debate, did not automatically resolve the conflicts (Torre et al., 2006), because opponents judged regulatory standards insufficient, whereas farmers found that complying with standards did not automatically put an end to their problems with their neighbours. Criticisms of the work practices of farmers became genuine challenges; all the more that diffuse pollution is difficult to link to individual responsibility. Problems of nitrogen management can also be considered in terms of calling their practices into question. The literature also shows that this uncomfortable situation was amplified by cyclic crises involving various sectors of livestock farming systems, accentuating competition and occasionally resulting in the social isolation of livestock farmers and the lack of interest by socio-professional organisations and associations (Bonnaud and Nicourt 2006a, Gadrey, 1990; de Gasparo et al., 2006).

Some work in sociology pointed out (Bonnaud and Nicourt, 2006b), however, that criticisms or social cohabitation could just as well make the profession difficult as to 'welcome it back to society'. When criticisms were levelled against odours, the attitude of the farmer in question was judged by their manuring practices: rapidly plough under, notify of planned manuring dates, changing times or fields treated, etc. All these taken together are signs that the expectations of neighbours are considered when faced with the variety of constraints. In a word, to anticipate the uses of shared space is a precautionary measure enabling the work of the livestock farmer to re-enter the social fabric.

A complex legal framework not enabling goals to be reached In France, the Nitrates Directive (12 December 1991) is perceived as the heart of legislation on nitrogen by the stakeholders involved. The aim of this Directive was to respond to both agricultural and environmental objectives by considering 'while the use of nitrogen-containing fertilizers and manures is necessary for Community agriculture, excessive use of fertilizers constitutes an environmental risk; that common actions I needed to control the problem arising from intensive livestock production and that agricultural policy must take greater account of environmental policy' (Rec. no. 3). The ambivalent status of nitrogen, that is, resource and/or pollutant, requires legal systems to find the just and permanent balance between the agricultural potential of animal waste with respect to the land receiving it, and its potential impacts on the environment. In other terms, the law does not call the fertilising qualities of livestock farm waste into question, but aims at limiting their possible negative effects on the environment and public health. This alternative is still valid today as shown by the title of a recent colloquium of the Academy of Agriculture of France: 'Animal waste: threat or value?' (Académie d'Agriculture de France 2010). Since year 2000, aspects of the legal system addressing the quality of water are covered by the Water Framework Directive (WFD, Directive 2000/60/EC), of which the Nitrates Directive is an integral part (Doussan, 2002 and 2006; Langlais, 2011). 


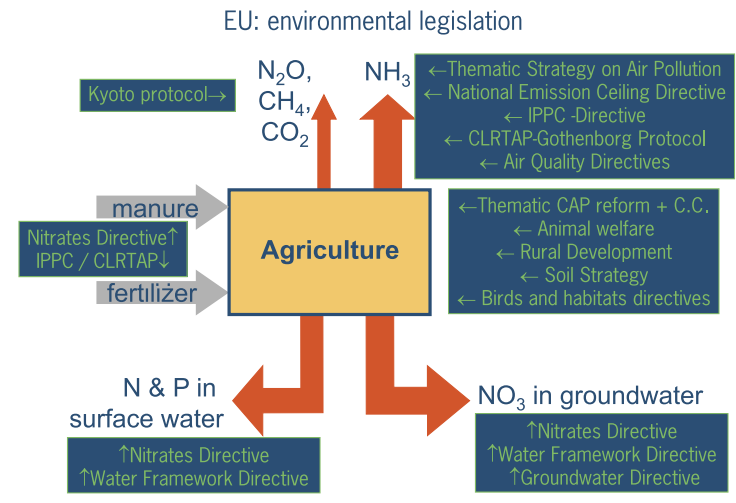

Figure 1 Representation of different policies depending on their links with agriculture and nitrogen emissions (from Kuikman 2012).

Agricultural nitrogen emissions are also covered by other protocols and Directives involving air quality, climate change or the quality of ecosystems, as shown in Figure 1. The Nitrates Directive acts at several levels but not as substantially as could be suggested by the analysis of French socio-economic publications.

\section{A multiplicity of zoning laws of variable constraints}

The Nitrates Directive is based on the delimitation of vulnerable zones that are 'zones in which water is affected by pollution and those that could be. For fresh surface waters, a maximal admissible concentration of nitrate in waters destined for the production of drinking water is set at $50 \mathrm{mg}$ per litre. For underground water, the same negative impacts threshold characterises vulnerability of the zone. For other bodies of fresh water as well as estuaries and coastal and sea water, the relevant definition adopted is eutrophication or the risk of eutrophication'. Ministerial Decree No. 93-1038 contained the inventory of vulnerable zones in France. This spatial designation was the subject of an EU litigation. Since more than 10 years, France was found guilty (CJCE, 27 June 2002) of poor identification of eutrophised water and was again questioned on this zoning in 2011 (Lacroix et al., 2006).

In areas concerned by the Nitrates Directive, Member States must implement an action programme. One of the main measure is to respect the upper limit for animal waste spreading at $170 \mathrm{~kg}$ of nitrogen/ha AA/year (articles R-211-80 and after of the Code of the Environment). ${ }^{1}$ Use of chemical fertilisation is not limited, neither thus total nitrogen input to the plant-soil system, but fertilisation plan must keep within the framework of balanced fertilisation. Since 2009, two new obligations for complying with the WFD concern (i) maintaining a $5 \mathrm{~m}$ (at least) wide band of grass or trees along the watercourses and (ii) ensure soil is covered during periods with nitrate leaching risks (Doussan, 2009). The fourth action programme, covering the period 2009 to 2013, is the subject of litigation with the European Commission.

${ }^{1}$ The treatable surface deduced from the UAS of legumes, those whose use is restricted except unused industrial land and those excluded for particular reasons (regulatory distances from watercourses, oyster and seafood farming, catchments, etc.). This surface generally accounts for $70 \%$ to $100 \%$ of UAS.
In addition, for France, inside 'vulnerable zones' were defined structural excess zones (SEZ), when 'the total quantity of livestock production waste produced annually would lead to, if the totality was used on the treatable surfaces of the canton (township), an annual nitrogen supply greater than $170 \mathrm{~kg}$ per hectare of this treatable surface' (article R. 211-82 of the Code of the Environment). In 'SEZ cantons', the Prefect (representative of the French government) can limit the quantity of total nitrogen produced by animals 'as long as structural nitrogen excess from livestock farming systems in the township is not resorbed', but a waiver may be accorded to newly installed farmers or small operations (Langlais, 2010). In actual fact, the effect of these rules was above all to distribute access to 'treatable' land that gave rise to a 'manuring surfaces' market (see Delaby et al., 2014, in this issue).

The Nitrates Directive also called for complementary action zones (CAZ) for drinking water supply catchment basins when their nitrate concentrations are higher than $50 \mathrm{mg} / \mathrm{l}$. Whereas SEZ concern only organic nitrogen inputs, CAZ consider total nitrogen inputs limited to $210 \mathrm{~kg} \mathrm{~N} / \mathrm{ha} \mathrm{per}$ year and the government can impose 'good agricultural practices for the management of water resources'. Nevertheless, France employed another zoning system to implement the Decree of 8 March 2001 of the European Court of Justice that concerns three Breton departments where water nitrate contents exceeded the ceiling-standard of $50 \mathrm{mg} / \mathrm{l}$ (Decree No. 2007-1281). More recently, the Grenelle 2 Act (No. 2010-788) delimited new zones concerning drinking water supply catchment areas and, above all, coastal catchments affected by green tides. In drinking water catchments, the administrative authority can limit land use to permanent extensive pastures or cultures receiving little or no inorganic fertiliser, with the possibility of compensating farmers as a counterpart. In the case of coastal areas subjected to algal blooms, all users or producers of nitrogen (farmers, public and private users of animal waste, and fertilisers suppliers) have to declare the quantities of nitrogen produced and the locations of manure application. It also sets the ceiling of $210 \mathrm{~kg}$ total N/ha of AA. The Grenelle 2 Act states that requirements can be taken outside vulnerable zones, even if drinking water standards are not exceeded.

These different zoning systems and applications resulted in a legal architecture that is complex, sometimes to the point of confusion. Evidently, they share, totally or partially, the same health and/or environmental objectives, but each corresponds to particular legal requirements as legal logic in France is that each Directive has its own object and means of implementation. The ultimate aim and the origin of nitrogen impacts on different bodies of water and are, nevertheless, often the same.

\section{Legislation on industrial and agricultural sites classified for} environmental protection

The legal system concerning nitrogen does not involve only the protection of aquatic environments against nitrate, but also includes legislation on production by 'industrial and 
agricultural sites classified for environmental protection' (ICPE in French). In this context, only the polluting load (defined in 1.2) from livestock farming systems determines the nature of requirements and not the area in which the farm is located.

As direct 'descendent' of the Decree of 1810, legislation on industrial and agricultural sites classified for environmental protection governs activities with the greatest risks of pollution. Activities of livestock farming systems may be subjected to a declaration, registration or authorisation, depending on their size. Authorisations require the owner or operator to conduct a preliminary impact study including the management of manure. The impact study is the subject of a public survey (posters displayed in a radius of 1 to $3 \mathrm{~km}$ around the farm). It is then presented to the Department Council of the Environment, Health and Technology Risks and the application is finally approved or rejected by a Prefectoral operation authorisation. The establishment of provisional manuring plans is a frequent cause of objections in the course of public inquiries and Prefectoral decrees. This manuring plan is often denounced as largely theoretical, especially if it involves cropland made available for spreading by other farmers (Baron et al., 2001). This 'land lending' depends on the non-binding consent of the contracting party (or parties) and requires the breeder (who provides manure) to be responsible for results that he does not de facto implement himself (Lessirard and Quevremont, 2008). Some authors noted that this loophole in the legal system was little brought to light. This can be explained by the fact that 'lending land' echoes historical solidarity among farmers. More recently, a Decree dated 17 January 2011 (law on the modernisation of agriculture and fishing of 27 July 2010) enables the waiving the obligation to provide an impact study when there is a merging or modernisation of the agricultural sites classified for environmental protection, if the project does not lead to 'a substantial change', or a 'noteworthy' increase in animal populations. This new and controversial amendment is too recent to be analysed.

\section{Incentive programmes}

The third aspect explored by politicians is voluntary procedures. In the framework of the Nitrates Directive, the agricultural profession initially negotiated the Ferti-Mieux (Fertilise Better) programme (1991) followed by the Programme for Control of Agricultural Pollutions (PMPOA, 1993). Several publications have described these systems that are within the 'co-management' policies of the sector and recount the experience of contracts in industry that implement regulatory arrangements in the name of pragmatism (Lascoumes, 1994).

Ferti-Mieux (Sebillote et al., 1996) arose from the work of the CORPEN (steering committee composed of scientists, professionals and public authorities between 1995 and 2009) quantifying soil nitrogen balances at the scale of individual farms. Ferti-Mieux proposes that farmers 'rationalise' their agricultural practices as a counterpart to recognising their preoccupation with preserving water quality. Adhesion to the contract is not based on an evaluation of results (nitrate contents of water), however, but on an 'obligation of means' (production practices). The reason is that there are too many hydrologic unknowns that prevent the establishment of a direct link between agricultural practices and nitrate contents of water (diffuse pollution, response time of hydrological process). The effectiveness of the system has suffered, even if some operations stand out by seeking to go beyond the obligation of means by monitoring water quality (Doussan, 2002; Nicourt and Girault, 2002; Brun, 2003).

The PMPOAs (1 and 2 - from 1993 to 2007) explicitly targeted bringing livestock farming systems into standards, although Ferti-Mieux involved primarily large-scale farming. Signed by the largest professional agricultural organisations, Ministries in charge of Agriculture and Environment, the PMPOAs proposed public participation towards costs $(20 \%$ to $25 \%$ ) of bringing into standards. In all, 90000 breeders have benefited (including 70000 cattle farmers) and animal waste storage capacities have almost doubled. The evaluation of the second PMPOA programme conducted by the French Breeders' Institute has linked efforts by farmers to the reduction of nitrate contents in Brittany waters since the early 2000s, although without being able to precisely distinguish the contribution from PMPOA2 and the concomitant reduction of the poultry population ( $-30 \%$ in Brittany).

\section{Severe evaluations}

Even though it involves institutional publications, it should be noted that a long series of reports from various government departments has evaluated public policies implemented to reduce water pollution by nitrate, especially in western France. The first report by S. Hénin (1980) recommended, in particular, that regulations guarantee real consequences on the environment rather than formal compliance with the procedure (Hénin, 1980). The evaluation on PMPOA stated that 'public authorities pay so that standards - obligatory by definition are applied' (Cahart et al., 1999). The most recent report by the 'Cour des Comptes' (government expenditures oversight agency) negatively proclaimed 'a lack of long-term determination by the government to question agricultural practices, marked by encouraging increased productivity and the choice of intensive agriculture' and expressed concerns on the risk of the government losing credibility with respect to reaching the goals of the WFD (Cour des Comptes, 2010).

These administrative evaluations have been corroborated by several scientific publications (Berlan, 1988; Lascoumes, 1995), identifying certain features as negative factors: (1) the diffuse character of agricultural pollutions, which in France has justified a collective approach to nitrogen excesses without individual responsibility by farmers, in contrast to, for example, the Dutch system that prefers a farm-by-farm regulatory approach (Bourblanc and Brives, 2009); (2) concerning agriculture, the inclusion of economic and social preoccupations in environment policies thus adapting their environment objectives, for example, protection of water resources, to the development of agricultural activity and not the inverse; (3) the application of the Nitrates Directive that places environmental legal objectives in the hands of 
agricultural development bodies (chambers of agriculture, cooperatives and farm groups). This could bias the professional identity of these bodies and also transform the regulatory environmental injunction into political incentive for medium-term professional change (development strategy).

Finally, water pollution control policies often concern administrative scales (farm, townships and department) having little relevance in terms of the hydrographic system or even irrelevant in terms of policy sector at stake. One study has shown that although public institutions co-finance bringing farms up to standards or remunerate environmental services related to 'good agricultural practices', they are also aware that the effectiveness of this financing is limited because of the unsuitability between the scale of the problem - the catchment area - and that of the environmental service rendered at the level of a farm.

\section{The notion of critical load to better understand atmospheric pollutions}

Whereas scientific publications in the recent past in France have focused on the nitrate issue, national, European Community and international laws have long concentrated on the polluting nature of atmospheric emissions, in particular, ammonia. The 1979 Geneva Convention was the first international accord to acknowledge the environmental and health problems caused by the passage of atmospheric pollutants across borders (Nilsson and Edwards, 2003). This was followed by commencing political and scientific cooperation for the surveillance of environment compartments that could be contaminated by these pollutants, as well as their effects on public health. This in turn resulted in the creation of eight protocols, the last of which, the Gothenburg Protocol of 1 December 1999, addressed acidification and eutrophication of ecosystems and tropospheric ozone. The European Commission has made a commitment to reduce by almost half of the excess acid deposits in regions, where ecosystems are subjected to eutrophication, by 2020 . This would require reducing ammonia emissions by $27 \%$. To reach this goal, the Commission is relying on both the Industrial Emissions Directive (No. 2010/75/EU, replacing the IPPC Directive) that must be transposed into national legislation no later than 7 January 2014, and the National Emissions Ceilings Directive.

Proven by biogeochemistry and ecology work by the international scientific community, the vulnerability of atmospheric pollution receiver ecosystems is at the core of the Gothenburg Protocol by the notion of critical load. This indicator is 'the quantitative estimation of exposure to one or several pollutants below which there is no notable harmful effect, in the current state of knowledge, on identified and sensitive elements of the environment'. The notion of critical load is based on regularly undated 'inventories' (surveys) and scientific estimations to assess the contextual capacity of the ecosystem to receive a polluting load and to define vulnerability zoning and the extent of measures to take. On the other hand, it does not set down a direct link between the polluting source and the impact, any more than zoning concerning nitrate. Finally, and above all, there remain gaps in the scientific understanding of methods that can be used for monitoring and assessing the critical load and risks if this value is exceeded.

\section{The spatial concentration of productions amplifies the impacts of nitrogen pollutions}

One aspect of the economic literature deals with the cause and effect relationships between economic logic that favours concentration of animal production systems and the regional impacts of nitrogen pollutions. This is because a high geographic animal density concentrates volumes of waste and thus nitrogen surplus discharged into the environment. This concept has been verified in western France (Brittany, Pays de la Loire, Basse-Normandie). International publications, primarily American, have confirmed the determining weight of the logic of concentration of livestock farming systems.

The United States is not the only country concerned by this issue. EC policies have addressed the geographic distribution of ruminants in France. The management of milk quotas in France has thus been used as an instrument to stabilise the regional milk supply and to reduce concentration. The suckler cow premiums, relating to permanent grazing land, and compensatory allowance scheme for areas with natural handicaps have all helped to maintain the presence of animal production in less favoured areas. Production strategies based on quality have also contributed to the development of these zones of livestock production. Inversely, swine and poultry production have been indirectly supported by EU organisations of cereal markets. As a result, these sectors have grown in a more liberal framework.

This section focuses on the logic of concentration and thus does not deal with all livestock farming regions. Nor does it consider all the consequences of concentration (jobs, added value of products, other pollutions, interactions with other activities, etc.).

\section{Specialisation at the origin of concentration of livestock farming systems}

The economic logic underlying agricultural specialisation can be explained as follows: the savings for some production factors, realised when a production installation expands, are greater than those resulting from reducing purchases of inputs (energy, inorganic fertilisers) that are lower in farm systems, combining plant and animal productions. Specialisation was substantially favoured by low energy prices and, in particular, by low price of chemical nitrogen fertiliser in the 1980 s and 1990s. These were consequently used more and more in place of organic nitrogen, nearly considered as waste but still spread without taking into account their fertilisation value. This change also enhances the value of specific talents and decreases costs of internal organisation when compared with a farm that uses several areas of competence. In addition, larger farms have more leverage to negotiate supplies of inputs and save on transaction and transportation costs. In economic terms, this means that economies of scale - the more produced, the less it costs per unit produced - in agriculture are generally greater than economies of scope gains resulting from synergies between production factors. 
Table 1 Changes in the largest production systems

\begin{tabular}{|c|c|c|c|c|}
\hline Type of herd & Population segment & 2000 & 2010 & Animals in 2010 \\
\hline Dairy cows & 80 heads and more & $25 \%$ & $33 \%$ & 2569817 \\
\hline Suckling cows & 200 heads and more & $21 \%$ & $36 \%$ & 7034317 \\
\hline Sheep & 900 heads and more & $15 \%$ & $19 \%$ & 1430263 \\
\hline Sows & 200 heads and more & $36 \%$ & $54 \%$ & 611419 \\
\hline Finishing pigs & 1500 heads and more & $28 \%$ & $33 \%$ & 2812100 \\
\hline Poultry & 50000 heads and more & $50 \%$ & $60 \%$ & 47012406 \\
\hline
\end{tabular}

Source: Agreste (2000 and 2010) agricultural surveys and structure investigation.

Table 2 Spatial concentration of animal productions in 2007 - percentage of animals per region of France

\begin{tabular}{lccccc}
\hline \hline & Dairy and suckling cows & Total cattle & Brood sows & Total pigs & Poultry \\
\hline Total numbers & 7786241 & 18594696 & 1026316 & 13865771 & 189086416 \\
Brittany & $11 \%$ & $10 \%$ & $55 \%$ & $56 \%$ & $39 \%$ \\
Pays de la Loire & $12 \%$ & $14 \%$ & $13 \%$ & $12 \%$ & $21 \%$ \\
Basse-Normandie & $8 \%$ & $9 \%$ & $4 \%$ & $4 \%$ & $2 \%$ \\
Grand Ouest & $31 \%$ & $37 \%$ & $72 \%$ & $72 \%$ & 0 \\
Number of regions with $5 \%$ to $10 \%$ & 4 & 4 & 0 & $19 \%$ & 19 \\
Number of regions with $<5 \%$ & 15 & 15 & 19 & 19 & 0 \\
\hline \hline
\end{tabular}

Detail of French 'Grand Ouest'; distribution of animal populations among the 21 regions in continental France.

As a result, farms are specialising and growing larger. Over the past 20 years in France, the numbers of meat and dairy cows/herd have more than doubled and those of pig production systems have increased sixfold (Table 1). Furthermore, not only has the average size of farms increased but production has concentrated in the largest livestock farming systems, regardless of the type of herd (Dupraz, 1997; Crespi et al., 2010; Chatellier and Dupraz, 2011).

Combining economies of scale and reduction of transport costs (collection, delivery of inputs, etc.) explains concentration at the regional scale (areas of varying size). Geographic proximity also provides other benefits: it facilitates the rapid circulation of information and the development of technical, organisational or product-related innovations. Animal production, in particular, pig and poultry production, are more concentrated geographically than other agricultural sectors (Table 2).

\section{Geographic concentration in the agro-industrial sector}

This concentration movement has been accompanied by industries upstream and downstream from production. As in the case of agricultural farms, the existence of economies of scale is a factor favouring spatial concentration of these industries. The geographic proximity of industry and farms results in increased efficiencies: producers are incentivised to be close to their clients to reduce the costs of transporting merchandise, to shorten delivery times, etc., explaining why companies in the same sector exert mutual attraction. These mechanisms operate in the pig and dairy sectors. It is to be noted that geographic proximity of 'raw materials' for feeding herds (wheat, barley, maize and soybeans) is not an important factor in the localisation of production (especially of pigs) partly because of relatively low maritime transport costs. The proximity to ports receiving shipments of soybeans from America, on the other hand, has been a positive factor in the concentration of animal production in Brittany (MacDonald and Ollinger, 2000; MacDonald and McBride, 2009).

Finally, the integration of livestock farming systems by industry also appears to favour the spatial concentration of production. This tendency is well illustrated by the poultry sector in France: $>90 \%$ of farmers have signed integration contracts $^{2}$ and more than $60 \%$ of poultry production is concentrated in Brittany and the Pays de la Loire (Table 2). In addition, several studies have pointed out that over the past 2 decades, the industry has strengthened its control over suppliers of agricultural products. In this perspective, reducing the number of suppliers minimises transaction costs.

The analysis of international economic publications confirms this phenomenon of clustering (agricultural, industrial and spatial concentration) in all European countries and in North America, although in varying proportions (Table 3).

\section{Is the logic of concentration reversible?}

Have environmental regulations reduced concentration, even led to a more balanced distribution of production in the country? Theoretically, limiting manuring, at a maximum per hectare, should favour the geographic dispersion of animal production as costs related to shipping waste to land still available for manuring are high, but this has not happened.

\footnotetext{
${ }^{2}$ Integration contracts in France date from the law of 6 July 1964. A farmer or group of farmers and one or several industrial or commercial companies sign a contract with reciprocal obligations for supplies of products or services to facilitate marketing agricultural products and to supply farmers.
} 
Langlais, Nicourt, Bourblanc and Gaigné

Table 3 Regional distribution of upstream and downstream industries

\begin{tabular}{lccccc}
\hline \hline & Butcher's meat & Poultry & Meat-based products meat & Dairy industry & Livestock feed manufacturing \\
\hline Number of jobs & 47957 & 28962 & 43253 & 53284 & 11376 \\
In Brittany & $24 \%$ & $11 \%$ & $21 \%$ & $7 \%$ & $34 \%$ \\
In Pays de la Loire & $18 \%$ & $13 \%$ & $16 \%$ & $7 \%$ & $16 \%$ \\
In Basse-Normandie & $4 \%$ & $10 \%$ & $2 \%$ & $9 \%$ & $2 \%$ \\
Grand Ouest & $46 \%$ & $34 \%$ & $39 \%$ & $23 \%$ & $52 \%$ \\
Number of regions with 5\% to 10\% & 1 & 3 & 3 & 15 & 1 \\
Number of regions with $<5 \%$ & 19 & 14 & 16 & 17 \\
\hline \hline
\end{tabular}

Percentage of jobs per region (detail of French western region (Brittany, Pays de la Loire, Basse-Normandie); distribution among the 21 regions in continental France).

Studies on the adaptation of livestock farming systems to the requirements of the Nitrates Directive in the Cotes d'Armor Department have shown that public subsidies to livestock farming systems in SEZs for the creation of treatment stations are more favourable to large farms, which can bear the costs of treatment. Treatment can even result in an increase in the size of livestock farms (economy of scale on the volume treated). Public support of these technologies, thus, in fact encourages spatial concentration. Thus, the region of Brittany concentrates $81 \%$ of volumes of liquid manure treated, whereas it accounts for 'only' half of hog productions (and $56 \%$ of the total herd). Economic work has shown that on the contrary, the milk quota policy froze the region's milk output. The end of EU milk quotas planned for 2015 could shift the decision-making axis to the industry side. In light of the economic mechanisms discussed above, this could favour the concentration of production. Finally, American studies have concluded that environmental policy needs to be severe and also applied stringently to affect the localisation of animal productions and that economies of clustering related to the proximity of industry have a larger effect on the spatial organisation of animal production (Chatellier and Vérité, 2003; Deuffic and Candau, 2006; Bouesse, 2010; Gaigné et al., 2011).

\section{References}

Académie d'Agriculture de France 2010. Elevages intensifs et environnement les effluents: menace ou richesse? Les colloques de l'Académie d'Agriculture de France 1-137.

Agreste. http://agreste.agriculture.gouv.frl. (consulted on 2014.08.014)

Autissier I. 2010. Pollution de l'eau: I'Etat doit mettre au pas I'agriculture industrielle. http://www.lemonde.fr/idees/article/2010/06/15/pollution-de-l-eau-Ietat-doit-mettre-au-pas-I-agriculture-industrielle_1373033_3232.html (consulted 2013-08-13)

Banos V and Candau J 2006. Recomposition des liens sociaux en milieu rural: de la fréquentation d'espaces à la production de normes collectives? Espaces et sociétés 4, 97-112.

Barles S and Lestel L 2007. The nitrogen question - urbanization, industrialization, and river quality in Paris, 1830-1939. Journal of Urban History 33, 794-812.

Baron P, Barthelemy F, Bouvier M, Martin X and Vogler JP 2001. Elevages et fonctionnement du Conseil départemental d'hygiène en Ille et Vilaine. IGECGGREF, Paris. 73pp.

Berlan JP 1988. La logique infernale des rendements agricoles. Lettre Echange Mediterranee 99, 14-15.

Bonnaud L and Nicourt C 2006a. La réorganisation du territoire de l'éleveur mise à l'épreuve des critiques de son travail. In Journées de la Recherche Porcine (ed. I-ITd Porc), pp. 241-246. Paris, France.
Bonnaud L and Nicourt C 2006b. Fragilisation de l'identité professionnelle des éleveurs de porcs et interpellation environnementale. In Rapport pour le Programme Porcherie Verte, p. 104, INRA, Paris.

Bouesse M 2010. Réduction des risques de pollution d'origine bovine. Agreste Primeur 240, 1-4.

Bourblanc $\mathrm{M}$ and Brives H 2009. La construction du caractère " diffus » des pollutions agricoles. Etudes Rurales 183, 161-176.

Brun A 2003. Aménagement et gestion des eaux en France: l'échec de la politique de l'eau face aux intérêts du monde agricole. Vertig0 4, 1-6.

Cahart P, Burgard LR, Joly A, Rogeau C, Benetière JJ, Gravaud A, Le Bail P and Vogler JP 1999. Rapport d'évaluation sur la gestion et le bilan du programme de maîtrise des pollutions d'origine agricole. Tome 1 rapport de synthèse. Tome 2 Annexes. Ministère de l'économie, des finances et de l'industrie, Inspection générale des Finances; Ministère de l'aménagement du territoire et de l'environnement, Conseil général du génie rural des eaux et forêts; Ministère de l'agriculture et de la Pêche, Comité permanent de coordination des inspections, Paris. 421pp.

Chatellier V and Vérité R 2003. L'élevage bovin et l'environnement en France: le diagnostic justifie-t-il des alternatives techniques? Productions Animales 16, 231-249.

Chatellier V and Dupraz P 2011. Politiques et dynamique des systèmes de production: Comment concilier compétitivité, défi alimentaire et environnement? 6. Edition. des Entretiens du Pradel, Mirabel, France, 15-16 septembre, 27pp.

Coquery M 1952. L'agriculture française et le plan de modernisation et d'équipement. Bulletin de la Société Française d'Economie Rurale 4, 76-81.

Cour des Comptes 2010. Les instruments de la gestion durable de l'eau Rapport public annuel 2010 de la Cour des comptes. Cour des comptes, Paris. 617-655.

Crespi JM, Xia T and Jones R 2010. Market power and the cattle cycle. American Journal of Agricultural Economics 92, 685-697.

de Gasparo S, Dejours C and Nicourt C 2006. Interpellations environnementales d'élevages et vécu au travail d'éleveurs. In Organisation et intensité du travail, pp. 335-343, Octarès, Toulouse.

Delaby L, Dourmad J-Y, Béline $F$, Lescoat $P$, Faverdin $P$, Fiorelli J-L, Vertès $F$, Veysset $P$, Morvan T, Parnaudeau V, Rochette P and Peyraud J-L 2014. Origin, quantities and fate of nitrogen flows associated with animal production. Advances in Animal Biosciences 5(S1), 28-47.

Deuffic $P$ and Candau J 2006. Farming and landscape management: how French farmers are coping with the ecologization of their activities. Journal of Agricultural \& Environmental Ethics 19, 563-585.

Doussan I 2002. Activité agricole et droit de l'environnement, l'impossible conciliation? L'Harmattan, Paris.

Doussan I 2006. La loi d'orientation agricole et la protection de l'environnement. Droit de l'Environnement 137, 100-104.

Doussan I 2009. Droit des pollutions azotées d'origine agricole. Jurisclasseur Environnement et Développement durable 4090, 1-44.

Dupraz P 1997. La spécialisation des exploitations agricoles: changements techniques et prix des facteurs. Cahiers d'Economie et Sociologie Rurales 45, 94-122.

Gadrey J 1990. Rapports sociaux de service: une autre régulation. Revue Economique 41, 49-70.

Gaigné C, Le Gallo J, Larue S and Schmitt B 2012. Does manure management regulation work against agglomeration economies? Evidence from France. American Journal of Agricultural Economics (in press). 
Gervais M, Servolin C and Weil J 1965. Une France sans paysans. Éditions du Seuil, Paris.

Guérin M 2005. Conflits d'usage à l'horizon 2020: quels nouveaux rôles pour l'État dans les espaces ruraux et périurbains? Commissariat général du plan, Paris.

Hénin S 1980. Activités agricoles et qualité des eaux. Rapport du groupe de travail. Ministère de l'agriculture; Ministère de l'environnement, Paris.

Kuikman PJ 2012. Personal communication, Alterra, WUR, The Netherlands

Lacroix A, Bel F, Mollard A and Sauboua E 2006. La territorialisation des politiques environnementales: le cas de la pollution nitrique de l'eau par l'agriculture. Développement Durable et Territoire 6, 1-14.

Langlais A 2010. Les mesures renforcées de la législation 'nitrates': perspectives d'une nouvelle dynamique environnementale bretonne. Revue juridique de I'Ouest 3, 313-334.

Langlais A 2011. Le droit de l'environnement et la nouvelle loi d'orientation agricole: la fin d'une relation passionnelle? Droit de l'Environnement 186 28-31.

Lascoumes P 1994. L'éco-pouvoir; environnement et politiques. La Découverte, Paris.

Lascoumes $P$ 1995. Les arbitrages publics des intérêts légitimes en matière d'environnement. Revue Française de Science Politique 45, 396-419.

Le Bourhis JP and Silvia B 2007. De l'expertise comme mode d'articulation entre I'Etat et les mouvements sociaux. Etude de deux réseaux d'acteurs autour de la gestion du territoire en France et en Italie (1975-2005). Congrès AFSP - Atelier 20 - 'Penser l'articulation entre l'analyse des politiques publiques et la sociologie de l'action collective', Toulouse, France, 5-7 September, 18pp.

Lessirard J and Quevremont P 2008. La filière porcine française et le développement durable. Ministères de l'écologie et de l'agriculture, Paris. 74pp. + annexes.
MacDonald JM and Ollinger ME 2000. Scale economies and consolidation in hog slaughter. American Journal of Agricultural Economics 82, 334-346.

MacDonald JM and MCBride WD 2009. The transformation of U.S. livestock agriculture: scale, efficiency, and risks. Electronic Information Bulletin 43, 46.

Massard-Guilbaud G 2010. Histoire de la pollution industrielle. Editions de I'EHESS, Paris.

Nicourt C and Girault JM 2002. Politiques réglementaires et politiques volontaires: un couple de prescriptions efficace pour limiter les pollutions d'origine agricole? INRA Sciences Sociales 15, 1-4.

Nilsson SI and Edwards A 2003. Element balances as sustainability tools. Selected papers from an international workshop, Uppsala, Sweden, 16-17 March 2001. European Journal of Agronomy 20, 125.

Ollitrault S 2001. Les écologistes français, des experts en action. Revue Française de Science Politique 51, 105-130.

Perrier-Cornet $P$ 2003. Quelles perspectives pour les campagnes françaises? Projet 274, 42-50.

Pierre G, Madeline P, Margetic C and Bermond M 2008. Durabilité, agricultures et territoires: quels questionnements pour les ruralistes d'universités de l'Ouest? Géocarrefour 83, 245-250.

Powlson DS, Addiscott TM. et al. 2008. When does nitrate become a risk for humans? Journal of Environmental Quality 37, 291-295.

Rémy J 1987. La crise de professionnalisation en agriculture: les enjeux de la lutte pour le contrôle du titre d'agriculteur. Sociologie du travail 4, 415-441.

Sebillote M, Allais C, Landais E and Lecoeur H 1996. Les mondes de l'agriculture: une recherche pour demain. INRA, Paris.

Torre A, Aznar 0 et al. 2006. Conflits et tensions autour des usages de l'espace dans les territoires ruraux et périurbains: Le cas de six zones géographiques françaises. Revue d'Economie Régionale et Urbaine 3, 415-453. 